\title{
Penyediaan Ruang Terbuka Hijau dengan Pendekatan Kota Hijau di Perkotaan Martapura
}

\author{
*Hanny Maria Caesarina, Dienny Redha Rahmani \\ Prodi Perencanaan Wilayah dan Kota, Fakultas Teknik, Universitas Muhammadiyah Banjarmasin \\ *hanny.planarch@gmail.com
}

\section{INFO ARTIKEL}

Riwayat Artikel:

Diterima: 11-2-2019

Disetujui: 23-5-2019

\section{Kata Kunci:}

Ruang terbuka hijau

Kota hijau

Perkotaan

Martapura

\section{ABSTRAK}

\begin{abstract}
Abstrak: Seiring meningkatnya urbanisasi, meningkat pula berbagai permasalahan yang dihadapi perkotaan terutama penurunan kualitas lingkungan. Konversi lahan dari ruang terbuka hijau menjadi lahan terbangun memunculkan efek urban heat island. Konsep kota hijau dengan penyediaan ruang terbuka hijau publik yang memadai merupakan salah satu upaya untuk mengantisipasi efek tersebut. Penelitian ini bertujuan untuk mengidentifikasi dan memetakan penyediaan ruang terbuka hijau publik pada perkotaan Martapura. Metode yang digunakan adalah deskriptif kuantitatif dengan pendekatan kota hijau. Hasil penelitian menunjukkan bahwa kawasan perkotaan Martapura memerlukan penambahan ruang terbuka hijau dalam bentuk rth aktif dan rth pasif.
\end{abstract}

Abstract: Urbanization has grown rapidly and causing series of urban problems, especially environmental degradation. Land conversion from green space into built environment gives a negative effect of urban heat island. Green city concept with green spaces is one of the effort to overcome those problems. This research intended to identify and mapping public green open space in urban area of Martapura. The method used in this research was descriptivequantitative with green city concept as the approach. The result shows that urban area in Martapura need additional public green open space in forms of active and passive green space.

\section{A. LATAR BELAKANG}

Urbanisasi di dunia telah menghasilkan perubahan dramatis pada pola tata guna lahan, efek negative pada keberlanjutan lingkungan kota dan wilayah sekitarnya[1] . Menurut PBB, dalam rentang waktu 2010-2050, populasi warga yang tinggal di perkotaan dunia akan meningkat dari 51,5\%-67,2\%, kurang lebih setara dengan 6 juta jiwa [2], [3]. Wilayah perkotaan di dunia menutupi $2 \%$ dari total lahan dan telah menghabiskan $75 \%$ sumber daya alam. Hal ini juga menyebabkan wilayah perkotaan menjadi penyumbang terbesar dalam dampak perubahan iklim dan konsumsi energi [4].

Adapun di benua Asia, Asia Tenggara termasuk salah satu wilayah yang paling sedikit memiliki wilayah perkotaan. Meskipun demikian, pertumbuhan penduduknya tercatat 1,75 kali lebih cepat dibandingkan dengan pertumbuhan penduduk perkotaan dunia [5].
Pertumbuhan penduduk yang sangat cepat ini menyebabkan peningkatan permintaan akan kualitas infrastuktur dan pelayanan public, serta penurunan kualitas lingkungan merupakan hal yang umumnya terjadi pada kota-kota di Asia Tenggara.

Begitu pula dengan Indonesia, urbanisasi telah menyumbangkan sekitar $49,8 \%$ penduduk tinggal di wilayah perkotaan dan akan meningkat menjadi $66,6 \%$ pada tahun 2035. Dengan rata-rata pertumbuhan penduduk pertahun $1,49 \%$, dominasi wilayah terbesar yang terkena dampak urbanisasi adalah pulau Jawa [3].

Seiring dengan meningkatnya arus urbanisasi, meningkat pula berbagai permasalahan yang dihadapi perkotaan seperti penurunan kualitas lingkungan. Polusi udara, polusi air dan polusi tanah merupakan beberapa dampak negative yang dapat dengan mudah ditemukan di perkotaan. Banyaknya ruang terbuka hijau yang dikonversi menjadi lahan terbangun pun kerap 
menimbulkan efek urban heat island atau peningkatan suhu thermal pada kawasan tertentu di perkotaan[6] [7].

Konsep kota hijau merupakan salah satu upaya yang telah digunakan berbagai negara di dunia untuk menanggulangi berbagai permasalah yang ada di perkotaan. Ada 8 (delapan) atribut yang ada dalam kota hijau [8], antara lain: green planning and design (perencanaan dan perancangan hijau); green open space (ruang terbuka hijau); green transportation (transportasi hijau); green energy (energi hijau); green building (bangunan hijau); green waste (persampahan hijau); green water (sistem pengairan yang efektif); green community (komunitas hijau).

Martapura adalah salah satu kota di provinsi Kalimantan Selatan yang aktif menggalakkan konsep kota hijau[9]. Salah satunya yang paling mendapatkan perhatian adalah tentang ketersediaan ruang terbuka hijau pada Kawasan perkotaannya.

\section{B. METODE PENELITIAN}

Metode yang digunakan dalam penelitian ini adalah deskriptif kuantitatif. Pendekatan yang digunakan adalah kota hijau, khususnya atribut green open space (ruang terbuka hijau/RTH). Pengumpulan data mengenai titik-titik ruang terbuka hijau pada perkotaan Martapura dilakukan dengan teknik observasi dengan menggunakan GPS dan kemudian dipetakan dengan metode NDVI sesuai panduan kota hijau[8].

Data yang telah diolah kemudian dibandingkan dengan dokumen-dokumen perencanaan yang telah ada serta keadaan eksisting sehingga mendapatkan luasan ruang terbuka hijau eksisting pada perkotaan Martapura. Berdasarkan hasil Analisa tersebut kemudian dihitunglah kebutuhan RTH untuk perkotaan Martapura berdasarkan luas wilayah, jumlah penduduk, kebutuhan oksigen dan penyediaan pohon untuk selanjutnya menentukan lokasi yang memungkinkan untuk pengembangan RTH pada perkotaan Martapura.

\section{HASIL DAN PEMBAHASAN}

Pertambahan jumlah penduduk di kawasan perkotaan menyebabkan permukiman berkembang dengan cepat dan tidak terkendali di kawasan perkotaan. Hal ini menyebabkan kebutuhan akan ruang di perkotaan meningkat. Sehingga permintaan ruang permukiman semakin tinggi dan berdampak pada merosotnya kualitas lingkungan perkotaan. Pentingnya kebutuhan ruang terbuka hijau ditegaskan dalam Undang-Undang Nomor 26 Tahun 2007 tentang Penataan Ruang yang bertujuan mewujudkan ruang kawasan perkotaan yang aman, nyaman, produktif, dan berkelanjutan.

Proporsi $30 \%$ luasan ruang terbuka hijau kota merupakan ukuran minimal untuk mencapai keseimbangan ekosistem kota baik keseimbangan sistem hidrologi dan keseimbangan mikroklimat, maupun sistem ekologis lain yang dapat meningkatkan ketersediaan udara bersih yang diperlukan masyarakat, ruang terbuka bagi aktivitas publik serta sekaligus dapat meningkatkan nilai estetika kota.

Konsep kota hijau merupakan salah satu konsep perencanaan kota [10]-[12] yang telah diterapkan di dunia dan turut diterapkan pula di Martapura. Sebagai kota yang dikenal dengan nama "Serambi Mekkah", Martapura merupakan salah satu kota di Kalimantan Selatan yang telah aktif menerapkan konsep kota hijau.

Ada 2 jenis ruang terbuka hijau, antara lain:

1. Ruang Terbuka Hijau Aktif,

Merupakan ruang terbuka yang memiliki fungsi sebagai tempat kegiatan manusia di dalamnya. Ruang terbuka hijau ini biasanya dengan dilengkapi elemenelemen pendukung taman bermain antara lain ayunan, petung, bangku taman dan sebagainya.

\section{Ruang Terbuka Hijau Pasif,}

Merupakan ruang terbuka yang memiliki fungsi bukan sebagai kegiatan manusia. Biasanya ruang terbuka ini hanya sebagai elemen estetis saja, sehingga kebanyakan untuk menjaga keindahan tanaman di dalam taman tersebut akan dipasang pagar di sepanjang sisi luar taman

\section{Ruang Terbuka Hijau menurut RTRW Kabupaten Banjar}

Berdasarkan Perda RTRW Kabupaten Banjar No. 3 Tahun 2013, Ruang terbuka hijau yang selanjutnya disebut RTH adalah area memanjang/jalur dan/atau mengelompok yang penggunaannya lebih bersifat terbuka, tempat tumbuh tanaman, baik yang tumbuh secara alamiah maupun yang sengaja ditanam.

Ketentuan Kawasan Ruang Terbuka Hijau Perkotaan:

a. RTH privat $10 \%$ terdiri atas :

1) Pekarangan rumah tinggal;

2) Halaman perkantoran, pertokoan dan tempat usaha;

3) Taman; dan

4) Lapangan olahraga.

b. RTH publik $20 \%$ terdiri atas :

1) RTH taman dan hutan kota terdiri atas :

a) Taman RT, taman RW, taman kelurahan dan taman kecamatan;

b) Taman kota meliputi tugu selamat datang, kanan dan kiri saluran irigasi, dibawah jembatan pesayangan dan dalam pagar;

c) Hutan kota di Indrasari; dan

d) Sabuk hijau (green belt).

2. RTH jalur hijau jalan terdiri atas :

a) Pulau jalan dan median jalan;

b) Jalur pejalan kaki; dan

c) Ruang dibawah jalan layang.

3. RTH fungsi tertentu terdiri atas :

a) RTH sempadan rel kereta api;

b) Jalur hijau jaringan listrik tegangan tinggi;

c) RTH sempadan sungai; 
d) RTH sempadan pantai;

e) RTH pengamanan sumber air baku/mata air;

f) Lapangan olahraga; dan

g) Pemakaman.

\section{RTH di Martapura}

Berdasarkan data indentifikasi dari Dinas Perumahan dan Permukiman. Titik RTH yang teridentifikasi berada dalam deliniasi Kecamatan Martapura Kota yang saat ini masih belum diberi SK Bupati dapat dilihat pada tabel 1.

Tabel 1.

RTH di Martapura

\begin{tabular}{|c|c|c|c|}
\hline & Nama Taman & Lokasi Taman & $\begin{array}{l}\text { Luas } \\
\text { (Ha) }\end{array}$ \\
\hline 1. & $\begin{array}{l}\text { Taman Kantor } \\
\text { Bupati Banjar }\end{array}$ & $\begin{array}{l}\text { Jl. A. Yani No. } 2 \text { Kab. } \\
\text { Banjar }\end{array}$ & 1,06 \\
\hline 2. & $\begin{array}{l}\text { Taman DPRD } \\
\text { Banjar }\end{array}$ & $\begin{array}{c}\text { Jl. A. Yani No. } 3 \text { Kab. } \\
\text { Banjar }\end{array}$ & 0,32 \\
\hline 3. & $\begin{array}{l}\text { Taman Kantor } \\
\text { Disperkim } \\
\text { (depan) }\end{array}$ & $\begin{array}{l}\text { Jl. P.Hidayatullah } \\
\text { No. } 2\end{array}$ & 0,03 \\
\hline 4. & $\begin{array}{l}\text { Taman Balai } \\
\text { Pemuda }\end{array}$ & Jl. Batuah Martapura & 0,44 \\
\hline 5. & $\begin{array}{l}\text { Taman Tugu } \\
\text { Pancasila }\end{array}$ & Jl. A Yani Km. 40 & 0,03 \\
\hline 6. & $\begin{array}{c}\text { Taman } \\
\text { Albasia/stadion } \\
\text { barakat }\end{array}$ & Jl. Albasia & 1,34 \\
\hline 7. & $\begin{array}{c}\text { Taman RTH Eks } \\
\text { Raza }\end{array}$ & $\begin{array}{c}\text { RTH Eks Raza } \\
\text { (RSUD Ratu Zaleha) }\end{array}$ & 1,02 \\
\hline 8. & Taman CBS & Jl. A. Yani Km. 39 & 1,07 \\
\hline 9. & $\begin{array}{l}\text { Taman Mahligai } \\
\text { Sultan Adam }\end{array}$ & $\begin{array}{l}\text { Mahligai Sultan } \\
\text { Adam }\end{array}$ & 0,66 \\
\hline 10. & Taman Kompas & $\begin{array}{c}\text { Komplek Pangeran } \\
\text { Antasari }\end{array}$ & 0,01 \\
\hline 11. & $\begin{array}{l}\text { Taman Rumah } \\
\text { Wabup }\end{array}$ & Jl. A Yani Km. 38.9 & 0,06 \\
\hline 12. & $\begin{array}{l}\text { Taman Irigasi } \\
\text { Zona } 1-4\end{array}$ & Jembatan Sei. Paring & 0,37 \\
\hline 13. & $\begin{array}{l}\text { RTH kawasan } \\
\text { tugu selamat } \\
\text { datang }\end{array}$ & $\begin{array}{l}\text { RTH tugu selamat } \\
\text { datang }\end{array}$ & 0,23 \\
\hline 14. & $\begin{array}{l}\text { Taman Samping } \\
\text { SMP } 1 \text { Mtp }\end{array}$ & Samping SMP 1 MTP & 0,02 \\
\hline 15. & $\begin{array}{l}\text { Taman Jl. } \\
\text { Pendidikan }\end{array}$ & Jl. Pendidikan & 0,12 \\
\hline 16 & $\begin{array}{l}\text { Taman Disperkim } \\
\text { (belakang) }\end{array}$ & $\begin{array}{c}\text { Komplek Pangeran } \\
\text { Antasari }\end{array}$ & 0,02 \\
\hline 17 & Taman Lansia & Jl, Albasia & 0,02 \\
\hline 18 & $\begin{array}{l}\text { Taman Kantor } \\
\text { Inspektorat }\end{array}$ & Kantor Inspektorat & 0,02 \\
\hline 19 & RTH Albasia & Kelurahan Jawa & 0,27 \\
\hline 20 & $\begin{array}{c}\text { Taman Kelurahan } \\
\text { Jawa }\end{array}$ & Jl. A. Yani Km. 38.9 & 0,00 \\
\hline
\end{tabular}

Sumber: Hasil Analisa, 2018

Berdasarkan hasil analisa NDVI, didapatkanlah titik-titik ruang terbuka hijau pada perkotaan Martapura sebagaimana terlihat pada gambar 1. Ruang terbuka hijau eksisting yang ada sekarang polanya menyebar dan belum merata.

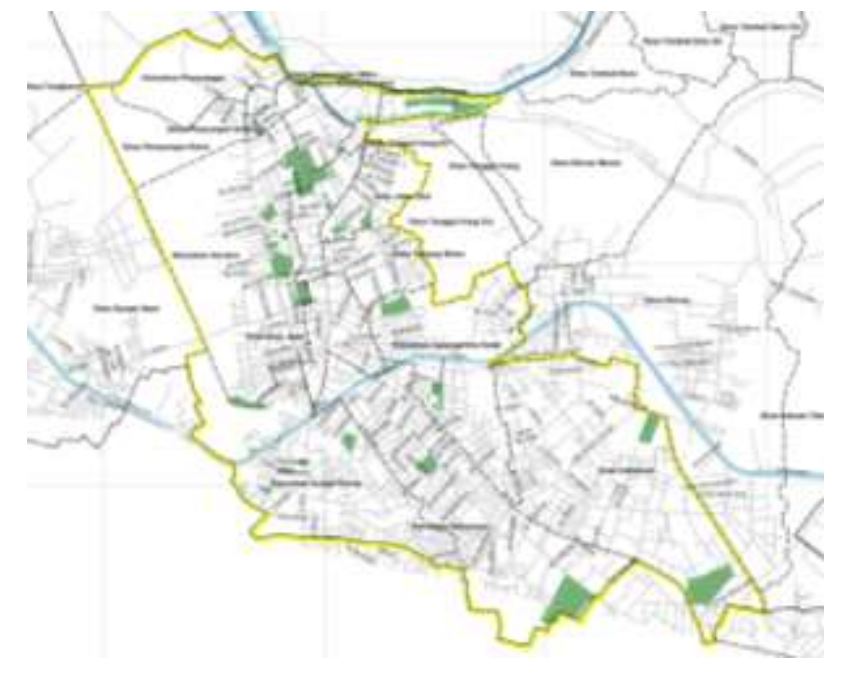

Gambar 1. Persebaran RTH Eksisting di Kota Martapura Sumber: Hasil Analisis, 2018

Dengan luas deliniasi kawasan kota hijau yaitu 1337, 33 Ha. Luasan RTH Publik yang teridentifikasi dalam RDTR dan Data Inventaris RTH Publik adalah hanya sebesar 43,84 Ha. Artinya total luasan RTH publik di Kawasan Kota Martapura adalah sebesar 3\% dari luas kota.

\section{Perhitungan RTH di Martapura}

a. Kebutuhan RTH Publik Martapura berdasarkan Luas Wilayah Kota

Menurut World Health Organization (WHO) kebutuhan green space, ruang terbuka hijau, per kapita adalah $9 \mathrm{~m}^{2}$ [14]. Menurut beberapa penilitian, luasan ini terlalu kecil untuk sebuah kota yang layak dan nyaman (liveable). Luasan minimal $9 \mathrm{~m}^{2}$ hanya bisa diaplikasikan apabila penghijauan dapat tercapai, aman, dan green space benar-benar digunakan oleh masyarakat. Penelitian-penelitian lanjutan menyarankan luasan ideal per kapita adalah $50 \mathrm{~m}^{2}$.

Apabila perhitungan ini diaplikasikan pada kebutuhan RTH Kawasan Kota Martapura, maka sesuai dengan masa perencanaan masterplan RTH sekitar 20 tahun, di tahun 2038 kebutuhan green space Kawasan Strategis Kabupaten Banjar adalah 371.460 Hektar.

Tabel 2

Perhitungan RTH di Martapura

\begin{tabular}{|c|c|c|c|}
\hline NO & $\begin{array}{c}\text { UNIT } \\
\text { LINGKUNGAN }\end{array}$ & $\begin{array}{c}\text { Proyeksi } \\
\text { Jumlah } \\
\text { Penduduk } \\
\text { Tahun } \\
2038\end{array}$ & $\begin{array}{c}\text { Kebutuhan } \\
\text { RTH } \\
\text { Menurut } \\
\text { WHO (m²) }\end{array}$ \\
\hline $\mathbf{1}$ & $\begin{array}{l}\text { Kecamatan } \\
\text { Martapura }\end{array}$ & 159.017 & 1.431 .153 \\
\hline 2 & $\begin{array}{c}\text { Kecamatan } \\
\text { Martapura Barat }\end{array}$ & 21.986 & 197.874 \\
\hline 3 & $\begin{array}{c}\text { Kecamatan } \\
\text { Martapura Timur }\end{array}$ & 22.603 & 203.427 \\
\hline 4 & $\begin{array}{l}\text { Kecamatan Karang } \\
\text { Intan }\end{array}$ & 209.128 & 1.882 .152 \\
\hline & TOTAL & 412.734 & 3.714 .606 \\
\hline
\end{tabular}

Sumber: Hasil Analisa, 2018 


\section{b. Kebutuhan RTH Publik Martapura berdasarkan} Jumlah Penduduk

Untuk menentukan luas RTH berdasarkan jumlah penduduk, dilakukan dengan mengalikan antara jumlah penduduk yang dilayani dengan standar luas RTH per kapita sesuai dengan peraturan yang berlaku. Kebutuhan RTH berdasarkan kapasitas pelayanan sesuai jumlah penduduk, dengan standar $1 \mathrm{~m}^{2}$ /penduduk adalah [13] :

1) Taman untuk unit RT $\approx 250$ penduduk, sekurangkurangnya diperlukan $250 \mathrm{~m}^{2}$ atau dengan standar $1 \mathrm{~m}^{2} /$ penduduk

2) Taman untuk unit RW $\approx 2.500$ penduduk, dibutuhkan minimal $1.250 \mathrm{~m}^{2}$ atau dengan standar $0,5 \mathrm{~m}^{2} /$ penduduk yang lokasinya dapat disatukan dengan pusat kegiatan RW lainnya, seperti balai pertemuan, pos hansip dan sebagainya.

3) Taman dan lapangan olah raga untuk unit Kelurahan $\approx 30.000$ penduduk, diperlukan lahan seluas 9.000 $\mathrm{m} 2$ atau dengan standar 0,3 $\mathrm{m}^{2} /$ penduduk.

4) Taman dan lapangan olah raga untuk unit Kecamatan $\approx 120.000$ penduduk, diperlukan lahan seluas $24.000 \mathrm{~m}^{2}(2,4$ hektar $)$ atau dengan standar $0,2 \mathrm{~m}^{2} /$ penduduk.

5) Jalur hijau dibutuhkan seluas $15 \mathrm{~m}^{2}$ /penduduk yang lokasinya menyebar

6) Besarnya lahan kuburan/pemakaman umum tergantung dari sistem penyempurnaan yang dianut sesuai agama dan kepercayaan masing-masing. Acuan perhitungan luasan berdasarkan angka kematian setempat dan/atau sistem penyempurnaan.

Sebagaimana terlihat pada tabel 3, kebutuhan RTH berdasarkan jumlah penduduk untuk perkotaan Martapura adalah sebesar 15,6 Ha.

\section{c. Kebutuhan RTH Publik Martapura berdasarkan} Kebutuhan Oksigen

Udara yang mengandung oksigen digunakan oleh mahluk hidup untuk proses pembakaran bahan bakar (respirasi) di dalam tubuh organisme untuk menghasilkan energi agar dapat bertahan hidup. Oksigen sangat dibutuhkan oleh manusia sekitar $67 \%$ dari tubuh manusia dan setiap manusia mengkonsumsi oksigen dalam jumlah yang sama sebesar 600 liter/hari atau 840 gram/hari (Gerakis 1974 dalam Wisesa 1988).

Berdasarkan Peraturan Menteri Pekerjaan Umum No 5/PRT/M/2008, kuantitas dan kualitas ruang terbuka publik terutama Ruang Terbuka Hijau (RTH) saat ini mengalami penurunan yang sangat signifikan dan mengakibatkan penurunan kualitas lingkungan hidup perkotaan yang berdampak pada kehidupan perkotaan terutama pada peningkatan pencemaran udara, dan menurunnya produktivitas masyarakat akibat terbatasnya ruang yang tersedia untuk interaksi sosial.

Pencemaran udara yang terjadi sangat berpengaruh terhadap ketersediaan oksigen untuk keberlangsungan hidup masyarakat perkotaan. Oksigen menjadi unsur yang penting bagi kehidupan, bahkan oksigen termasuk kedalam golongan unsur yang mudah bereaksi dengan banyak unsur lainnya. Oksigen sendiri termasuk ke dalam unsur yang banyak di muka bumi, yaitu berada di urutan ketiga dari gas yang melimpah di semesta, selain helium dan hidrogen.

Sebagaimana terlihat pada tabel 3, kebutuhan RTH berdasarkan kebutuhan oksigen untuk perkotaan Martapura adalah sebesar 372,36 Ha.

\section{d. Kebutuhan RTH Publik Martapura berdasarkan} Kebutuhan Pohon untuk Supplai O2

Dengan meningkatnya perkembangan pembangunan dan penduduk di Kota, terjadi penurunan luas lahan hutan atau vegetasi. Peningkatan kendaraan umum dan jumlah penduduk akan berimplikasi pada peningkatan gas buangan $\mathrm{CO} 2$ dan $\mathrm{CO}$ ke udara. Dengan semakin meningkatnya populasi penduduk, maka berdampak juga terhadap produktivitas pohon dan berpengaruh terhadap kualitas udara yang mengandung oksigen karena pencemaran udara yang disebabkan kendaraan umum.

Secara rata-rata, dalam daur hidupnya setiap pohon bisa mencukupi oksigen (O2) untuk kebutuhan 18 (delapan belas) orang dan menyerap karbondioksida (CO2) dari mobil yang berjalan sekitar $41.834 \mathrm{~km}$. Pohon besar menyerap kira-kira sebesar 120-240 pounds partikel kecil tau gas polutan. Hanya tumbuhanlah yang menghasilkan oksigen di bumi ini (Jalal 2007).

$$
\mathrm{N}=\frac{194.425}{18}=10.801,4
$$

\section{Kebutuhan RTH Kawasan Kota Martapura tahun 2028}

Tabel 3

Perhitungan RTH di Martapura

\begin{tabular}{|c|c|c|c|}
\hline No & $\begin{array}{l}\text { Kebutuhan } \\
\text { RTH }\end{array}$ & $\begin{array}{c}\text { Luas RTH } \\
\text { (Ha) }\end{array}$ & Keterangan \\
\hline \multirow[t]{5}{*}{$\mathbf{1}$} & $\begin{array}{l}\text { Berdasarkan } \\
\text { persentase } \\
\text { luas wilayah } \\
\text { kota (WHO) }\end{array}$ & 371.460 & RTH Pasif \\
\hline & $\begin{array}{l}\text { Kecamatan } \\
\text { Martapura }\end{array}$ & 143.115 & \\
\hline & $\begin{array}{l}\text { Kecamatan } \\
\text { Martapura } \\
\text { Barat }\end{array}$ & 19.774 & \\
\hline & $\begin{array}{l}\text { Kecamatan } \\
\text { Martapura } \\
\text { Timur }\end{array}$ & 20.347 & \\
\hline & $\begin{array}{l}\text { Kecamatan } \\
\text { Karang } \\
\text { Intan }\end{array}$ & 188.2 & \\
\hline \multirow[t]{5}{*}{2} & $\begin{array}{l}\text { Berdasarkan } \\
\text { jumlah } \\
\text { penduduk }\end{array}$ & 15,6 & RTH Aktif \\
\hline & $\begin{array}{l}\text { Kecamatan } \\
\text { Martapura }\end{array}$ & 11,7 & $\begin{array}{l}\text { Taman } \\
\text { kelurahan }\end{array}$ \\
\hline & & 0,875 & Taman rw \\
\hline & $\begin{array}{l}\text { Kecamatan } \\
\text { Martapura } \\
\text { Barat }\end{array}$ & 1 & Taman rw \\
\hline & $\begin{array}{l}\text { Kecamatan } \\
\text { Martapura }\end{array}$ & 0,9 & $\begin{array}{c}\text { Taman } \\
\text { kelurahan }\end{array}$ \\
\hline
\end{tabular}




\begin{tabular}{|c|c|c|c|}
\hline & \multicolumn{3}{|l|}{ Timur } \\
\hline & & 0,875 & Taman rw \\
\hline & Kecamatan & 0,25 & Taman rw \\
\hline & Karang & & \\
\hline & Intan & & \\
\hline \multirow[t]{16}{*}{3} & Berdasarkan & 129,28 & RTH Aktif \\
\hline & penambahan & & \\
\hline & jumlah & & \\
\hline & penduduk & & \\
\hline & tahun 2036 & & \\
\hline & Kecamatan & 88,34 & \\
\hline & Martapura & & \\
\hline & Kecamatan & 5,82 & \\
\hline & Martapura & & \\
\hline & Barat & & \\
\hline & Kecamatan & 4,10 & \\
\hline & Martapura & & \\
\hline & Timur & & \\
\hline & Kecamatan & 31,02 & \\
\hline & Karang & & \\
\hline & Intan & & \\
\hline \multirow[t]{13}{*}{4} & Berdasarkan & 372,36 & RTH Aktif \\
\hline & $\begin{array}{l}\text { kebutuhan } \\
\text { oksigen }\end{array}$ & & \\
\hline & Kecamatan & 189,9036 & \\
\hline & Martapura & & \\
\hline & Kecamatan & 145,2204 & \\
\hline & Martapura & & \\
\hline & Barat & & \\
\hline & Kecamatan & 18,618 & \\
\hline & Martapura & & \\
\hline & Timur & & \\
\hline & Kecamatan & 18,618 & \\
\hline & Karang & & \\
\hline & Intan & & \\
\hline \multirow[t]{15}{*}{5} & Berdasarkan & 10.801 & RTH \\
\hline & kebutuhan & & Aktif/Pasif \\
\hline & pohon untuk & & \\
\hline & suplai O2 & & \\
\hline & Kecamatan & 5508,51 & \\
\hline & Martapura & & \\
\hline & Kecamatan & 4212,39 & \\
\hline & Martapura & & \\
\hline & Barat & & \\
\hline & Kecamatan & 540,05 & \\
\hline & Martapura & & \\
\hline & Timur & & \\
\hline & Kecamatan & 540,05 & \\
\hline & Karang & & \\
\hline & Intan & & \\
\hline
\end{tabular}

\section{TEMUAN ATAU DISKUSI}

Berdasarkan RTRW Kabupaten Banjar 2013-2033, terdapat kawasan utama yang memenuhi syarat untuk dikembangkan sebagai kawasan dengan 8 atribut kota hijau, kawasan tersebut adalah:

- Kertak Hanyar

- Gambut

- Martapura

- Martapura Barat

- Martapura Timur

- Sungai Tabuk

- Aluh-Aluh

- Simpang Empat

Dari ke delapan lokasi prioritas tersebut, ada 3 kawasan yang termasuk di dalam Kawasan strategis Kota
Martapura, yaitu: Martapura, Martapura Barat, dan Martapura Timur.

Dalam menentukan kawasan yang diprioritaskan untuk pembangunan RTH baru, digunakan pertimbangan ahli yang berdasar RAKH Kabupaten Banjar. Pertimbangan-pertimbangan tersebut antara lain:

a. Kesesuaian dengan Rencana Tata Ruang

Lokasi prioritas harus sesuai dengan yang tercantum pada Rencana Tata Ruang, karena pembangunan RTH juga harus selaras dengan Rencana Tata Ruang yang berlaku sehingga pembangunannya dapat terus berlanjut secara berkesinambungan.

b. Jumlah Penduduk

Jumlah penduduk menentukan tingkat keaktifan RTH publik, semakin banyak jumlah penduduk di lokasi RTH maka semakin besar pula potensi RTH tersebut untuk selalu aktif dan berfungsi optimal sebagai sarana sosial dan rekreasi.

c. Kondisi Sosial Ekonomi Masyarakat

Kondisi sosial ekonomi masyarakat di lokasi berpengaruh pada keberlanjutan suatu RTH, apabila kondisi ekonomi masyarakat tergolong pada ekonomi lemah maka dikhawatirkan RTH tersebut ke depannya akan beralih fungsi menjadi tempat untuk aktivitas perekonomian yang berakibat pada rusaknya RTH.

d. Kebutuhan RTH Taman Kota

Suatu kawasan menjadi lokasi pembangunan RTH juga dipertimbangkan pula kebutuhan kawasan terbut terhadap adanya RTH. Hal ini dapat dilihat dari eksisting RTH di kawasan tersebut, apabila telah banyak memiliki RTH maka ada baiknya pembangunan dialihkan pada kawasan yang belum memiliki RTH naming memiliki potensi.

e. Ketersediaan Lahan

Ada atau tidaknya lahan, dan luas lahan yang tersedia berpengaruh pada bentuk dan luasan RTH yang akan dibangun.

f. Termasuk dalam kawasan pengembangan baru

Apabila suatu kawasan termasuk dalam kawasan pengembangan baru, maka otomatis pembangunan akan menjadi lebih cepat. Hal ini berpengaruh juga pada pembangunan RTH, yaitu pada realisasi pembangunan.

g. Arahan pemerintah daerah

Arahan pemerintah daerah dan juga tokoh masyarakat sangat diperlukan dalam rangka menentukan lokasi RTH yang sesuai dengan kebutuhan suatu kawasan. Pembangunan RTH yang tidak sesuai dengan arahan Pemda dikhawatirkan akan melenceng dari RTR dan tidak sesuai dengan kebutuhan masyarakat.

h. Jarak dengan permukiman

Jarak dengan permukiman berpengaruh pada aktivitas dan keberlanjutan suatu kawasan RTH. Apabila jarak dengan permukiman terlalu jauh maka RTH tersebut bisa menjadi tidak aktif dan mati.

i. Jarak dengan sarana publik 
Jarak dengan sarana publik juga berpengaruh pada aktivitas RTH, semakin banyak sarana publik yang lokasinya dekat dengan RTH maka masyarakat juga akan semakin tertarik untuk beraktivitas di RTH tersebut.

\section{j. Aksesibilitas}

Aksesibilitas memiliki peran yang sangat penting dalam penentuan lokasi RTH, karena akses sangat menentukan apakah RTH tersebut akan berfungsi dengan optimal atau tidak, sebagus apapun bentuk atau desain RTH, tanpa akses yang mudah dan memadai maka RTH tersebut tidak akan berfungsi dengan baik.

Tabel 4

Skoring Penentuan Lokasi RTH

\begin{tabular}{|c|c|c|c|c|}
\hline $\begin{array}{l}\mathbf{N} \\
\mathbf{O}\end{array}$ & Pertimbangan & $\begin{array}{c}\text { Marta } \\
\text { pura }\end{array}$ & $\begin{array}{c}\text { Marta } \\
\text { pura } \\
\text { Barat }\end{array}$ & $\begin{array}{c}\text { Marta } \\
\text { pura } \\
\text { Timur }\end{array}$ \\
\hline $\mathbf{1}$ & $\begin{array}{l}\text { Kesesuaian dengan } \\
\text { rencana tata ruang }\end{array}$ & 4 & 3 & 3 \\
\hline 2 & Jumlah penduduk & 3 & 2 & 2 \\
\hline 3 & $\begin{array}{l}\text { Kondisi Sosial } \\
\text { Ekonomi } \\
\text { masyarakat }\end{array}$ & 4 & 2 & 3 \\
\hline 4 & $\begin{array}{l}\text { Kebutuhan RTH } \\
\text { Taman Kota }\end{array}$ & 3 & 2 & 2 \\
\hline 5 & $\begin{array}{l}\text { Ketersediaan } \\
\text { Lahan }\end{array}$ & 4 & 2 & 2 \\
\hline 6 & $\begin{array}{l}\text { Termasuk dalam } \\
\text { kawasan } \\
\text { pengembangan } \\
\text { baru }\end{array}$ & 2 & 3 & 3 \\
\hline 7 & $\begin{array}{l}\text { Arahan } \\
\text { Pemerintah Daerah }\end{array}$ & 3 & 2 & 2 \\
\hline 8 & $\begin{array}{l}\text { Jarak dengan } \\
\text { Permukiman }\end{array}$ & 2 & 2 & 1 \\
\hline 9 & $\begin{array}{l}\text { Jarak dengan } \\
\text { sarana publik }\end{array}$ & 4 & 2 & 3 \\
\hline \multirow[t]{2}{*}{$\begin{array}{l}\mathbf{1} \\
\mathbf{0}\end{array}$} & Aksesibilitas & 4 & 2 & 3 \\
\hline & TOTAL & 34 & 23 & 24 \\
\hline
\end{tabular}

Berdasarkan tabel di atas maka Kecamatan Martapura dapat dipilih sebagai lokasi pembangunan RTH baru. Dibandingkan dengan kecamatan Martapura Barat dan Timur, Kecamatan Martapura paling berpotensi karena ketersediaan lahan untuk RTH, memiliki jumlah penduduk yang mencukupi, kondisi sosial ekonomi masyarakat juga sangat mendukung.

Arahan pemerintah daerah juga menentukan Martapura sebagai lokasi paling potensial untuk pembangunan RTH baru. Beberapa lokasi yang sudah di identifikasi dan tercantum dalam RAKH 2015 adalah daerah Indrasari dan Bincau untuk peruntukan RTH serta Hutan Kota.

\section{E. SIMPULAN}

Luasan RTH Publik perkotaan Martapura yang teridentifikasi dalam RDTR dan Data Inventaris RTH Publik adalah hanya sebesar 43,84 Ha. Artinya RTH publik di Kawasan Kota Martapura hanyalah total seluas $3 \%$ dari luas kota.
Menurut hasil analisa, perkotaan Martapura memerlukan penambahan ruang terbuka hijau dalam kuantitas yang berbeda-beda sesuai dengan kriteria yang dipilih. Berdasarkan persentasi wilayah kota, diperlukan 371.460 Ha dalam bentuk RTH pasif; berdasarkan jumlah penduduk diperlukan 15,6 Ha RTH aktif; berdasarkan penambahan jumlah penduduk di tahun 2036 diperlukan 129,28 Ha RTH aktif; berdasarkan kebutuhan oksigen dibutuhkan 372,36 Ha RTH aktif; dan berdasarkan kebutuhan pohon untuk supplai O2 maka diperlukan 10.801 RTH aktif dan pasif.

\section{DAFTAR RUJUKAN}

[1] Z. Liu, C. He, and J. Wu, "General spatiotemporal patterns of urbanization: An examination of 16 world cities," Sustain., vol. 8, no. 1, pp.1-15, 2016.

[2] U. N. D. of E. and S. A. Division, "World Urbanization Prospects: The 2011 Revision," World urbanization prospects: the 2011 revision. p. 318, 2012.

[3] I. A. P. Indonesia, "Indonesia Most Livable City Index (MLCI) 2017.” IAP (ikatan Ahli Perencanaan Indonesia), Jakarta, p. 67, 2017.

[4] S. C. Sandhu and R. N. Singru, "Enabling GrEEEn Cities: An Operational Framework for Integrated Urban Development in Southeast Asia," ADB Southeast Asia Work. Pap. Ser., no. 9, 2014.

[5] B. Yuen and L. Kong, "Climate change and urban planning in Southeast Asia," SAPI EN. S. Surv. Perspect. Integr. Environ. Soc., vol. 2, no. 2.3, pp. 1-20, 2009.

[6] Y. Yamagata and H. Seya, "Simulating a future smart city: An integrated land use-energy model," Appl. Energy, vol. 112, pp. 1466-1474, 2013.

[7] D. Kyriazis, T. Varvarigou, D. White, A. Rossi, and J. Cooper, "Sustainable smart city IoT applications: Heat and electricity management \& Eco-conscious cruise control for public transportation," in 2013 IEEE 14th International Symposium on a World of Wireless, Mobile and Multimedia Networks, WoWMoM 2013, 2013.

[8] K. Pekerjaan Umum dan Perumahan Rakyat, D. Jenderal Cipta Karya, and D. Bina Penataan Bangunan, Panduan penyelenggaraan Program Pengembangan Kota Hijau, VI. Jakarta: Kemeterian Pekerjaaan Umum dan Perumahan Rakyat, Direktorat Jenderal CIpta Karya, Direktorat Bina Penataan Bangunan, 2017.

[9] Bappeda and K. Banjar, "Rencana Aksi Kota Hijau," Kabupaten Banjar, Indonesia, 2015.

[10] I. Prihartini, R. Noviani, and P. Wijayanti, "Model Penataan Ruang Terbuka Hijau (RTH) Perkotaan (Kasus Solo Green City)," 2013.

[11] G. Ferrer, S. Cortezia, and J. M. Neumann, “Green City," J. Ind. Ecol., vol. 16, no. 1, pp. 142152, 2012.

[12] B. V., F. Steinberg, and M. Lindfield, Green cities. Mandaluyong City, Philippines: Asian Development Bank, 2012.

[13] Direktorat Jendral Penataan Ruang. Department Pekerjaan Umum, Pedoman Penyediaan Dan 
Pemanfaatan Ruang Terbuka Hijau Di Kawasan Perkotaan. 2008, p. 84 p.

[14] WHO Regional Office for Europe, "Urban green spaces: A brief for action," pp. 1-24, 2017. 